\title{
Gaping Generation Gap in Preeti Shenoy's a Hundred Little Flames
}

\author{
B. Rathika
}

\begin{abstract}
The oeuvre of Preeti Shenoy is remarkable for her exquisite portrayal of characters. The title of the novel that is taken up for investigation is highly suggestive. A flame cannot brighten up or lead any one's life or path. But when many flames are put together it becomes a torch to walk with confidence even in darkness. The protagonist Ayan is humble in his desire and aim. His father prods him often to attain greater heights in his career. Ayan is neither determinate to achieve his goal nor passionate to set his goal. The generation gap between Ayan and his father is far wide, whereas his wave length astutely sinks with his grandfather. Ayan is able to cope with his grandfather but not with his father. It is not the age that brings discrepancies between father and son. The egoistic clash and the individual pride adhering to the prejudice widen the gap in the relationship among fathers and sons. This paper investigates the background of the gap and how it is resolved in the novel chosen.
\end{abstract}

Keywords: generation gap, modern and postmodern attitude , vie with each other, changing attitude bridge the gap.

\section{I.INTRODUCTION}

\section{$\mathrm{P}$} reeti Shenoy in her novel A Hundred Little Flames narrates the story of an old man, Gopal, whose hundred little flames (his desires) are doused off by his progenies. The crushed and crumpled soul of Gopal longs for a hold. Generation gap exists between his kids and him bring in multiple disruptions in his life. Gopal belongs to baby boomers generation (children born between 1945 and 1964, his progenies belong to generation X (1965-1980) and their progenies belong to generation $\mathrm{Y}$ (1981-1995). Generation Z belongs to the period between 1996 to the present.

Generation $\mathrm{Z}$ is the primary user of mobile from tertiary level. They prioritise digital world equal to reality. They stay connected with phones $24 \times 7$, in order to alleviate their boredom which ultimately drives them to be filled with dichotomies. Smart phones become nucleus of their daily life. Chats replace livelier chitchats at home. However these chats bring disruptions in the relationship. This paper investigates the generation gap that prevails among the main characters - Gopal, Jairaj, Shaila and Ayan.

And it will also discuss the reasons for generation gap, discrepancies that sprout from the gap, and aims to find out whether any possibility to overcome or bridge the gap.

\section{II.SUMMARY OF THE NOVEL}

Ayan, the protagonist of the novel does not have any wish on his own. He feels like a puppet in his father's hand. Though he is an obliging son, he is enforced to execute certain wishes of his father which he dislikes to the core. Ayan's stay at Thekke Madom(in Kerala) has changed his

Revised Manuscript Received on December 20, 2019.

Dr. B. Rathika, English, Mepco Schlenk Engineering College, Sivakasi, Tamilnad, India.. Email:rathikaanjac@gmail.com

perspectives about life. He agrees with his grandfather in many of his opinion. He is able to identify passion and genuineness of his grandfather's platonic love that exists between his grandfather and his ex-beloved. He realises the value of rustic life which is not tarnished by technology. The serene and eco-friendly life is juxtaposition of urban life. Altogether Ayan relieves himself from the monotony of mundane world. He sets his aim to revive his grandfather's dream.

\section{MODERNS VS POSTMODERNS}

Ayan's grandfather is not a pure modern. For instance his affinity towards his soil which has not felt the transformation or influence of technology is very strong. But when his grandson depends on technology he remains quiet and does not interrupt in his ways.

Fragmentation is prominent in both modernism and postmodernism. But that is accepted in "different moods" as pointed out by Jeremy Hawthorn in his Concise Glossary of Literary Theory. The modernist features in such a way as to register a deep nostalgia for an earlier age when faith was full and authority intact. (QTD Watt,181)

Ayan's grandfather is very nostalgic. He refuses to accept transformation. He adheres to metanarratives. Postmoderns do not adhere to grand narratives.

"......there is a tone of lament, pessimism and despair about the world which finds its appropriate representation in these 'fractured' art forms...."(Watt, 81 )

"For the postmodernist, by contrast, fragmentation is an exhilarating, liberating phenomenon,.......escape from the claustrophobic embrace of fixed system of beliefs. (Watt,81)

This is evident in the life of Ayan. Everything is lost for Ayan at one juncture. His life becomes fragmented desperate in his love and career. He is hopeful to pursue his life with confidence. He does not carry over his dejection after his failures. He adapts to the new environment in Thekke Madom. Besides he maintains good rapport with his grandfather. Ayan is his grandfather's ardent aide.

\section{IV.DISRUPTIONS IN DOMESTIC LIFE}

Gopal denies staying with his son who lives abroad. Thekke Madom is a palatial ancestral home of Gopal Sankar and his siblings lived together in a joint family.

"Little by little, the joint family had disintegrated with members moving away to different cities to make a living." (A Hundred,19)

Gopal's son Jairaj plans to sell their ancestral home and asks his father to stay with him in Bahrain. Gopal contends his son's plan saying : 
"People like to live in match boxes, where there is not even a piece of land". $(\mathrm{P}, 20) \mathrm{Gopal}$ is for 'minimalism'. He has grudges towards his son who prioritizes monetary development and socio-economic status. His son and daughter never value their source (the place in which they spent their childhood days and brought up).

\section{V.RAY OF HOPE}

Gopal finds a pot of gold in the form of his grandson who is able to sympathise him unlike his son. Ayan realizes his grandfather's affinity towards his place. Ayan's father defends his plan on the ground that "who is going to live in that huge house after him?"(P, 81). His father's words “fall like a stab to Ayan" $(\mathrm{P}, 81)$. What Jairaj is unable to cope with is realized by Ayan. He immediately thinks of his grandfather's plight once the home is sold.

Ayan knows that his father is very practical. Simultaneously he is able to sense that selling Thekke Madom is equal to that of uprooting his grandfather from a place to which he affixes to the core. Ayan's sadness is profound. This incident highlights that age is anot a barrier for generation gap. What a son fails to understand is understood by a grandson.

In Indian context, though it is primarily a patriarchal set up in the society, father and son relationship does not exist smoothly in majority of the cases. Most of them vie with one another. In the case of Gopal, his son and daughter fail to realize him.

\section{VI.TECHNOLOGY SHRINKS RELATIONSHIP}

It is a common expectation of a parent to see his progenies occasionally. Gopal's children are against his expectation. Both of them stay away from him. They never care to visit him. Phone calls and Skype connect them and that too for their material benefit in the view of Gopal. Gopal, who is stuck by traditional codes and conduct says:

Yes. Jairaj hasn't come here for thirteen years or may be more. I have stopped counting. He hasn't the title or heads unless they are unavoidable. He hasn't come here even after Akshu was born. The family tradition is to give a thulabaram at the devi kshetram. (P 102)

Gopal feels a lot toward his children's negligence. He too keeps himself away from his children and never expects anything from them. He leads an isolated life until the arrival of Ayan. The ego clash between the father and the daughter touches their raw nerve and kindles their fury. Gopal's friendship with his schoolmate Rohini leads to a wide gap between his family members and himself.

\section{VII.DOMESTIC MUTINY : CONSERVATIVE PERCEPTION OF LIFE}

Gopal is not given a chance to defend or justify the purity of his friendship with Rohini. Before he tries to sort out the issues his friend Rohini vanishes from his life mysteriously. It is Ayan who brings back Rohini and revives their friendship. Gopal's wife, Padmaja meets her end badly out of depression. Shaila strongly believes that it is father who has deserted her mother and killed her. Gopal gets through all his trouble all alone.
Lack of mutual understanding and humanitarian concern among family members leads to mishap. Jairaj cares his father yet he fails to understand his emotions and feelings. He never respects his father's individual expectation in his old age. According to Jairaj, nothing is essential for his father. This misconception pushes him to take a dreadful decision of admitting his father in an asylum. Again Ayan becomes Gopal's redeemer. Ayan distances himself from his father and does his best to reunite Rohini and Gopal. There is an unexpected twist in the end of the story. Gopal who meets with numerous ups and downs in his family life has been very determinate while facing oddities. On the contrary when he is about to meet Rohini after many decades unable to bear the jubilation, gives up his enthusiasm feels ache when he is at the reach of Rohini. He breathes his last in the place in Pondicherry where they have met numerous times. His departure proves that man's aboding assures him peace while he lives and when he dies.

\section{RIFT IN INTRAPERSONAL ACQUAINTANCES}

Intra personal relationship among family members irrespective of age is essential in order to maintain a healthy and peaceful relationship. Ego should be shirked off by all individuals in the family. Empathizing elders is very important to avoid them making feel that they are marginalized from the rest of the family members. Jairaj's rash decision in the novel widens cleavage between him and his son. Ayan becomes too rigid toward his father and plans to transform "Thekke Madom" to an art gallery with the help of Rohini by getting support from the Kerala government.

Ayan felt like a subservient to his father and fears him initially but now turns to be a determinate as well as independent individual saying:

.....having the courage to stand up to my father and tell him to fuck off. All my life I was afraid of him.

Now the only person I answer to, is myself. (P 360)

\section{IX.CONCLUSION}

Every individual should realize one's responsibility to maintain a strong relationship which is devoid of expectation. In order to patch up with the different generations irrespective of age differences individuals should shirk off their selfishness. Each one creates one's own trends and sticks to them badly because they want their comfort zone to be undisturbed by any external agent. Emanation of self-realization to create oneness among the family members to bridge the gaping gap is the solution to cover up the frictions that exist among the postmodern individuals.

\section{REFERENCES}

1. Barry, Peter. Beginning Theory. New Delhi: Vikas Limited, 2015.

2. https://en.m.wikipedia.org > wiki > Gener

3. https://www.investopedia.com > terms

4. https://www.vanityfair.com > ge.

5. https://www.google.com/url?sa=t\&source=web\&rct=j\&url

6. https://www.indiastudychannel.com/resources/136541- Generation

7. Shenoy, Preeti. A Hundred Little Flames. New Delhi: Westland Publications Limited, 2017. 


\section{AUTHOR PROFILE}

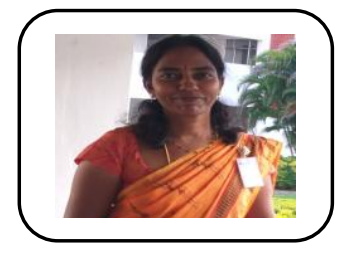

Dr. B. Rathika is the Assistant Professor in the Department of English at MEPCO SCHLENK Engineering College, Sivakasi. She has a decade of teaching experience in Ayya Nadar Janaki Ammal College, Sivakasi and a year of teachingexperience in Kalasalingam Academy of Research and Education. She has presented nearly ten papers in national and International Seminars and conferences. She has authored two books with ISBN numbers. She has applied for an ICSSR- IMPRESS Project on the title "Honing Communicative Skills of High School Rural Students". She has completed her proposal presentation and is awaiting for the result by Expert Committee members of ICSSR. Her area of specialization is Indian Bestsellers. She completed her Doctoral thesis on the title "Youth Themes in the Works of Preeti Shenoy, Chetan Bhagat and Ravinder Singh". She published ten papers in Journals with impact factors. She has organized One National Seminar and One International Conference in the year 2011 and 2017 respectively. She is the Speaking Examiner for BEC Preliminary and Vantage for the year 2018-2020. 